\title{
Prolonged neonatal hyperbilirubinaemia in a case of congenital hypopituitarism
}

\author{
Deepanjan Bhattacharya, Rakesh Kumar, ${ }^{\oplus}$ Devi Dayal
}

Department of Pediatrics, Post Graduate Institute of Medical Education and Research, Chandigarh, Chandigarh UT, India

\section{Correspondence to} Professor Rakesh Kumar, drrakesh.pgi@gmail.com

Accepted 22 January 2019

\section{DESCRIPTION}

A 2-month-old girl presented with prolonged neonatal jaundice along with progressive abdominal distension and intermittent passage of hard stools. There was no history of high coloured urine, clay coloured stool, poor feeding, lethargy or highpitched cry. There was no history of thyroid or liver disease in the family.

On examination, baby had icterus with carotenaemia tinge, along with hypertelorism, depressed nasal bridge, narrow palpebral fissures, macroglossia and short neck (figure 1A). She had stunting (length at $-5.15 \mathrm{z}$ score for age), with preserved weight and head circumference. Systemic examination was unremarkable except for abdominal distension with everted umbilicus. Investigations revealed macrocytic red blood cells (RBC) (Mean Cell Volume $105.7 \mathrm{fl}$ ) along with unconjugated hyperbilirubinemia ( $\mathrm{T}$ Bil: $19.06 \mathrm{mg} / \mathrm{dL}, \mathrm{C}$ Bil: $1.32 \mathrm{mg} / \mathrm{dL}$ ) along with mild elevation of transaminases (aspartate transaminase: $157 \mathrm{IU} / \mathrm{L}$, alanine transaminase: $89 \mathrm{IU} / \mathrm{L})$. Coagulogram was normal (Prothrombin Time: 14s, International Normalised Ratio: 1.00 , activated partial thromboplastin time : 33 s) and urine culture was sterile.

Haemolytic workup was unremarkable (normal glucose-6-phosphate-dehydrogenase, reticulocyte $2.39 \%$, and negative Coombs test, urine and plasma haemoglobin).

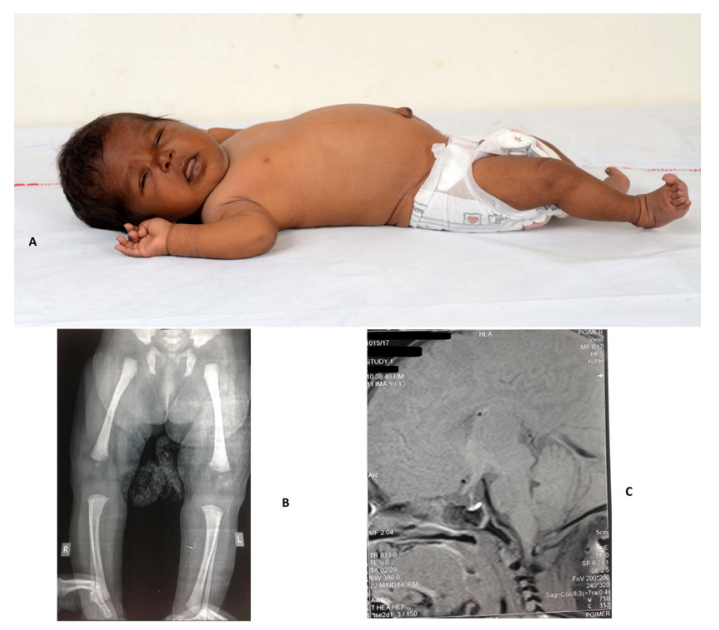

Figure 1 (A) Dysmorphic facies with carotenaemia tinge and distended abdomen with umbilical hernia. (B) Anteroposterior skiagram of bilateral knee joints showing absent tibial epiphyses. (C) MRI brain-T2 sagittal section showing reduced height $(1.5 \mathrm{~mm})$ and bulk of adenohypophysis, with normal stalk and posterior pituitary.
Ultrasonography of the abdomen revealed dilated bowel loops and USG neck revealed hypoechoic thyroid gland, with normal structure.

X-ray bilateral knee joint revealed absent tibial epiphysis (figure 1B).

Endocrinological investigations revealed secondary hypothyroidism (thyroid stimulating hormone (TSH): $0.026 \mu \mathrm{IU} / \mathrm{L}(0.27-4.2)$, T3: $0.397 \mathrm{nmol} / \mathrm{L}(0.8-2)$ and $\mathrm{T} 4: 0.587 \mu \mathrm{g} / \mathrm{dL}$ $(4.8-12.7))$. 08:00 hours cortisol $(343 \mathrm{nmol} / \mathrm{L})$ and adrenocorticotropic hormone $(42 \mathrm{pg} / \mathrm{mL})$ were normal; prolactin $(0.144 \mathrm{ng} / \mathrm{mL})$ and luteinising hormone $(\mathrm{LH})(0.980 \mathrm{mIU} / \mathrm{mL})$ were low with normal follicle stimulating hormone (FSH) $(19.99 \mathrm{mIU} / \mathrm{mL})$. Growth hormone $(\mathrm{GH})$ was low $(0.030 \mathrm{ng} / \mathrm{mL})$ in response to hypoglycaemia, while parathormone was normal $(10.23 \mathrm{pg} / \mathrm{mL})$. Insulin like growth factor 1 was also found to be low $(17.6 \mathrm{ng} / \mathrm{mL})$.

In view of panhypopituitarism, MRI pituitary gland was done which revealed reduced bulk and mildly decreased height of adenohypophysis $(1.5 \mathrm{~mm})$ (figure $1 \mathrm{C})$.

A diagnosis of congenital hypopituitarism, with secondary hypothyroidism was considered, and she was started on oral thyroxine supplementation, following which there was resolution of jaundice and transaminase levels became normal, along with improvement of growth.

Congenital hypothyroidism is a well-known cause of prolonged neonatal jaundice, and presents with other features like constipation, macroglossia, delayed closure of fontanelles, umbilical hernia, coarse facial features and macrocytic RBC.

However, central congenital hypothyroidism is a rare entity $(1: 20000-1: 50000)$ and is often missed on neonatal screening, where only TSH is measured.

The index child had deficiencies of GH along with TSH, prolactin and $\mathrm{LH}$, thereby qualifying as hypopituitarism, with probable mutation of PIT-1, a nuclear protein necessary for maturation and functioning of lactotrophs, somatotrophs and thyrotrophs. ${ }^{1}$

Cholestatic jaundice with hypopituitarism is well reported in literature. ${ }^{2}$ However, unconjugated hyperbilirubinaemia has been rarely reported to be associated with congenital hypopituitarism. There is one publication by Copeland et al in 1981, that congenital hyperbilirubinaemia, if associated with hypoglycaemia may warrant investigation for congenital hypopituitarism. ${ }^{3}$ However, our index child did not have any hypoglycaemic records. Hyperbilirubinaemia in the 


\section{Learning points}

- Unconjugated hyperbilirubinaemia may occur in hypopituitarism due to deficiency of thyroxine if cortisol is normal.

- Prolonged jaundice with stunting and facial dysmorphism mandates workup for central hypothyroidism.

- Panhypopituitarism must be ruled out in central congenital hypothyroidism.

index child is attributed to decreased conjugation of bilirubin, due to hypothyroidism.

Contributors DB: Patient management, literature review and preparation of the initial draft of the manuscript. RK: Patient management, literature review and preparation of the initial draft of the manuscript. DD: Clinician-in-charge, critical review of the manuscript for important intellectual content and final approval of the version to be published.

Funding The authors have not declared a specific grant for this research from any funding agency in the public, commercial or not-for-profit sectors.

Competing interests None declared.

Patient consent for publication Parental/guardian consent obtained.

Provenance and peer review Not commissioned; externally peer reviewed.

\section{REFERENCES}

1 Pfäffle RW, Blankenstein O, Wüller S, et al. Combined pituitary hormone deficiency: role of Pit-1 and Prop-1. Acta Paediatr Supp/ 1999;88:33-41.

2 Ellaway CJ, Silinik M, Cowell CT, et al. Cholestatic jaundice and congenital hypopituitarism. J Paediatr Child Health 1995;31:51-3.

3 Copeland KC, Franks RC, Ramamurthy R. Neonatal hyperbilirubinemia and hypoglycemia in congenital hypopituitarism. Clin Pediatr 1981;20:523-6.

Copyright 2019 BMJ Publishing Group. All rights reserved. For permission to reuse any of this content visit https://www.bmj.com/company/products-services/rights-and-licensing/permissions/

BMJ Case Report Fellows may re-use this article for personal use and teaching without any further permission.

Become a Fellow of BMJ Case Reports today and you can:

- Submit as many cases as you like

- Enjoy fast sympathetic peer review and rapid publication of accepted articles

- Access all the published articles

- Re-use any of the published material for personal use and teaching without further permission

For information on Institutional Fellowships contact consortiasales@bmjgroup.com

Visit casereports.bmj.com for more articles like this and to become a Fellow 